\title{
ARTIFICIAL HYBRIDIZATION WITHOUT EMASCULATION IN LIMA BEAN (Phaseolus lunatus L.) ${ }^{1}$
}

\author{
ANTÔNIA MARIA DE CASSIA BATISTA DE SOUSA ${ }^{2 *}$, VERÔNICA BRITO DA SILVA ${ }^{3}$, \\ ELLIDA DE AGUIAR SILVESTRE ${ }^{4}$, RAIMUNDO NONATO OLIVEIRA SILVA ${ }^{5}$, \\ ANGELA CELIS DE ALMEIDA LOPES ${ }^{3}$, REGINA LUCIA FERREIRA GOMES ${ }^{3}$
}

\begin{abstract}
This study aimed to validate the artificial hybridization without emasculation in lima beans, identifying $F_{1}$ generation using microsatellite markers (SSR). We used four accessions from the Active Germplasm Bank of Phaseolus, Universidade Federal do Piaui (BGP-UFPI), with contrasting growth habits and days-to-maturity traits. The 241 crosses performed had a percentage of hybrid pods of $5.8 \%$, obtaining 42 seeds in $F_{1}$. Artificial cross-fertilization was confirmed by microsatellite markers (BM 211, BM 141, BM 154, and GAT 591), and four plants were identified as hybrids. Thus, the proposed method is effective in performing artificial crosses for lima beans.
\end{abstract}

Keywords: Artificial crosses. Friction method. Microsatellite marker.

\section{HIBRIDAÇÃO ARTIFICIAL SEM EMASCULAÇÃO EM FEIJÃO-FAVA (Phaseolus lunatus L.)}

RESUMO - Este estudo teve como objetivo validar a hibridação artificial sem emasculação em feijão-fava, identificando a geração de F1 utilizando marcadores de microssatélites (SSR). Foram utilizados quatro genótipos do Banco Ativo de Germoplasma de Phaseolus da Universidade Federal do Piauí (BGP-UFPI), com hábitos de crescimento e maturidade contrastantes. Os 241 cruzamentos realizados apresentaram percentual de vagens híbridas de 5,8\%, obtendo 42 sementes na F1. O cruzamento artificial foi confirmado pelos marcadores microsatélites (BM 211, BM 141, BM 154 e GAT 591), e quatro plantas foram identificadas como híbridas. Assim, o método proposto é eficaz na realização de cruzamentos artificiais em feijões-fava.

Palavras-chave: Cruzamentos artificiais. Método de fricção. Marcadores Microssatélites.

\footnotetext{
${ }^{*}$ Corresponding author

${ }^{1}$ Received for publication in 10/01/2020; accepted in 08/12/2021.

Paper was extracted from the first author's term paper.

${ }^{2}$ Department of Plant Genetics and Breeding, Universidade Federal do Goiás, Goiânia, GO, Brazil; antonia.sousaufpi@gmail.com ORCID: 0000-0002-3329-1364.

${ }^{3}$ Department of Plant Sciences, Universidade Federal do Piauí, Teresina, PI, Brazil; verabritosl@hotmail.com - ORCID: 0000-0001-77395061, acalopes@ufpi.edu.br - ORCID: 0000-0002-9546-5403,rlfgomes@ufpi.edu.br - ORCID: 0000-0002-7700-6959.

${ }^{4}$ Department of Plant Genetics and Breeding, Universidade de Campinas, Campinas, SP, Brazil; ellidaguiar@gmail.com - ORCID: 00000002-9133-4094.

${ }^{5}$ Department of Plant Sciences, Universidade Federal do Piauí, Floriano, PI, Brazil; jraio@ufpi.edu.br - ORCID: 0000-0002-9987-0043.
}

Rev. Caatinga, Mossoró, v. 35, n. 1, p. 223 - 230, jan. - mar., 2022 


\section{INTRODUCTION}

Lima bean (Phaseolus lunatus L.) is the second most important socioeconomic species of the genus Phaseolus (ORMEÑO ORRILLO et al., 2015). In Brazil, it is used as a food source in the form of green or ripe grains, besides being an income option for small producers (GRANJA et al., 2019). The states of Ceará, Pernambuco, Paraíba, Maranhão, Rio Grande do Norte, Piauí, Sergipe, Alagoas, and Bahia, in descending order, are the largest producers, and together make the Northeast the largest producing region, with 18,882.36 tons of grain (IBGE, 2018). The cultivation in the Northeast has been evolving with the use of new technologies and cultivation in larger areas. However, it still occurs in a rustic way since there is no availability of improved cultivars, due to the lack of an adequate hybridization method, which hinders a breeding program. Furthermore, data on its floral biology and pollination are limited and, in Brazil, there are practically no studies on these themes (PENHA et al., 2017).

The lack of improved cultivars for growing regions in Brazil justifies the used of artificial hybridization methods to take advantage of genetic variability within the species. Hybridization without emasculation in lima beans is crucial if compared to other species such as Phaseolus vulgaris, in which emasculation is performed, as it has small floral buds (up to $7.56 \mathrm{~mm}$ ). Moreover, the aggressiveness of this technique can damage structures of the floral bud, especially the stigma, causing failure of the hybridization (SILVA et al., 2016, ANTUNES et al., 2010).

Confirmation of cross-fertilization is crucial in validating a hybridization method. For this purpose, microsatellite molecular markers have been useful tools since they are independent of environmental effects and plant physiological stage, allowing early and accurate identification of individuals with a better combination of favorable alleles (PENHA et al., 2017). For the species, Phaseolus lunatus, SSR markers are efficient in differentiating many populations and their clustering patterns, gene flow, phylogenetic analysis, as well as research on domestication and dispersal of the species (MARTÍNEZ-CASTILLO et al., 2014; FÉLIX; COELLO-COELLO; MARTÍNEZCASTILLO, 2014; PENHA et al., 2017; RUIZ-GIL, et al., 2016).

Thus, this study aimed to validate the method of making artificial crosses without emasculation in lima beans, with confirmation of hybridization through microsatellite markers.

\section{MATERIALS AND METHODS}

The experiment was conducted under Sombrite ${ }^{\circledR}$ protective screen with $40 \%$ shading intensity, in the Plant Science Department of the Universidade Federal do Piaui (UFPI), in the city of Teresina, Piauí State, Brazil. The area is located at $74.4 \mathrm{~m}$ altitude, with mean geographic coordinates of $05^{\circ} 5^{\prime} \mathrm{S}$ and $42^{\circ} 49^{\prime} \mathrm{W}$, and mean annual rainfall of $1350 \mathrm{~mm}$.

Four accessions from the Active Germplasm Bank of Phaseolus, Universidade Federal do Piauí (BGP - UFPI), were used as parents, which contrasted mainly in growth habits and days-tomaturity traits. The accessions UFPI 628 and UFPI 728 have determinate growth habit and early maturity, while UFPI 666 and UFPI 465 have indeterminate growth habit and a late-cycle (SOUSA et al., 2015)

Seeds were sown in 24 15-L pots, constituted by six pots per genotype, at 34-day intervals between accessions with determinate (early maturity) and indeterminate (late cycle) habits. Two seeds were sown per pot in a substrate composed of soil and goat manure (2: 1). A thermo-hygrometer, Minipa MT-241, was installed on the protective screen to record temperature and humidity conditions throughout the crossing period.

To determine flowering time, 30 flower buds among 12 plants were marked at random with colored ribbons and directly observed at one-hour intervals in the morning and the afternoon (RANGEL JÚNIOR et al., 2018). During the morning, the plants were observed from 7:00 to 11:00, and in the afternoon, from 1:00 to 6:00, with the number of open flowers being recorded. The student's $t$-test was applied to test the null hypothesis of equality between the mean values of open flowers in both periods, adopting a confidence interval of $95 \%(p<0.05 \%)$. This information is fundamental to determine the suitable period for performing artificial crosses.

Artificial hybridizations were performed according to Bliss (1980) and included the following steps. a) The bud to be used as pollen receptor (female parent) was chosen and had to be adult and fully closed to ensure sufficient maturity to receive pollen and develop seeds, ruling out the risk of selfpollination. b) The ideal bud selected (mature and in pre-anthesis) was open with the aid of tweezers, cutting the petals surrounding the male and female organs on the concave side of the flower bud, and lightly pressing the base of the flower ovary to expose the stigma without damaging so that pollen grains from the male parent could be received. c) A 
freshly-opened flower from the male parent was selected, from which the perianth was detached, and then the base of its ovary pressed so that the stigma with pollen was exposed. This was made because the flower was beginning to self-pollinate, that is, the anther had released pollen grains to the stigma, but they had not yet been induced to the pollen tube and were concentrated at the tip of the stigma. d) The pollen-donating stigma was collected and then placed within the receptor stigma to receive the pollen grains from the other parent and induce them to the pollen tube, thus inducing cross-fertilization. e) Finally, adhesive tape was placed around the flower for protection, and a tag was placed on the peduncle of the inflorescence with the name of the female and male parents, respectively, as well as the date of pollination and initials of the person who performed the cross-pollination (Figure 1).

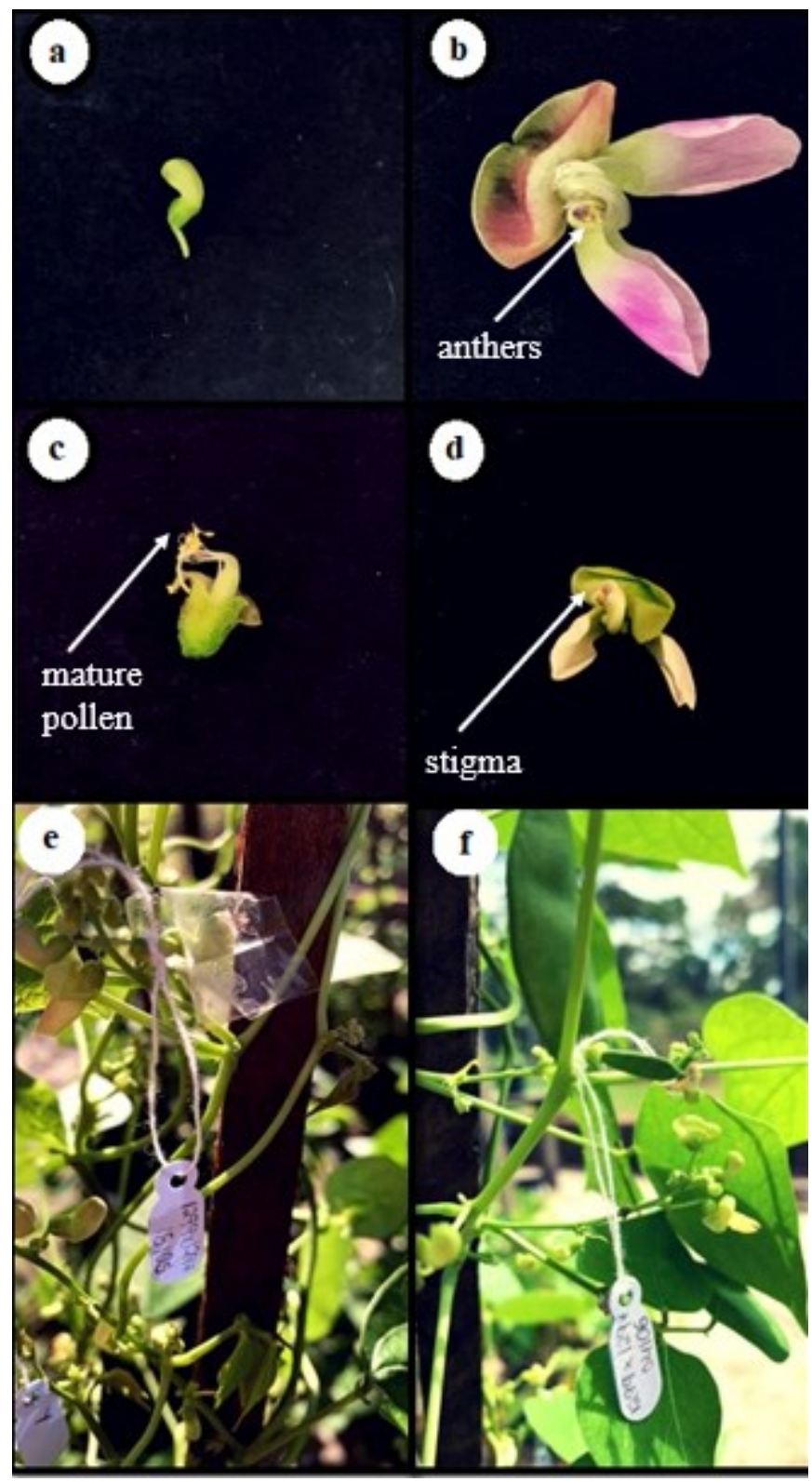

Figure 1. Parent preparation for artificial crossing using the friction method. a) a mature, hooded flower bud chosen to be a female parent. b) freshly-opened flower selected as the male parent, from which the perianth was detached, and then the base of its ovary was pressed to expose the pollen grains. c) Standard, wing and keel petal removal to collect the mature pollen. d) flower bud showing the stigma after the incision of mature pollen grains in the female parent. e) tape around the flower for protection and tag on the peduncle of the inflorescence for identification. $\mathrm{f}$ ) pod formed after artificial crossing.

From April to July of 2015, 241 crosses were performed from 8:00 to 11:00 a.m. and from 4:00 to 6:00 p.m., according to the time established as having a greater frequency of flower anthesis. Within these periods, the number of attempts between each combination of parents and success in establishing a hybrid pod set was registered, and the percentage was calculated (Table 1). 
A. M. C. B. SOUSA et al.

Table 1. Percentage (\%) of crosses performed and pod sets in each cross combining different lima bean (Phaseolus lunatus L.) genotypes.

\begin{tabular}{|c|c|c|c|c|c|}
\hline Combination identification & Combination* & $\mathrm{N}^{\mathrm{o}}$ crosses performed & Crosses performed $(\%)$ & $\mathrm{N}^{\mathrm{o}}$ pod set & Pod set $(\%)$ \\
\hline 1 & UFPI 628 X UFPI 465 & 24 & 10 & 1 & 4 \\
\hline 2 & UFPI 628 X UFPI 666 & 27 & 11 & 4 & 16 \\
\hline 3 & UFPI 728 X UFPI 465 & 22 & 9 & 1 & 5 \\
\hline 4 & UFPI 728 X UFPI 666 & 19 & 8 & 2 & 11 \\
\hline 5 & UFPI 666 X UFPI 728 & 29 & 12 & 0 & 0 \\
\hline 6 & UFPI 666 X UFPI 628 & 22 & 9 & 2 & 11 \\
\hline 7 & UFPI 465 X UFPI 628 & 43 & 18 & 2 & 5 \\
\hline 8 & UFPI 465 X UFPI 728 & 55 & 23 & 2 & 4 \\
\hline
\end{tabular}

*In each combination, the first genotype represents the female parent and the second, the male parent.

Over the time crosses were performed, data on the minimum and maximum temperatures, and relative humidity were collected under the protective screen.

The Pearson correlation coefficient between the percentage of hybrid pod sets and climatic elements (minimum and maximum temperatures and relative humidity) were estimated under the conditions in which the artificial crosses were performed. Statistical-genetic analyses were carried out using the GENES software (CRUZ, 2013). Seeds from potential artificial crosses were managed under the same experimental conditions as the parents and evaluated for growth habits and days to maturity. The seeds were sown in pots with one $F_{1}$ seed per pot. At 15 days after emergence, leaves from each cross combination were collected for DNA extraction and later molecular analysis. The parents were evaluated by the same molecular analysis.

DNA was extracted from the accessions used as parents and plants obtained from crosses using the CTAB protocol, described by Doyle and Doyle (1990). In both cases, 11 primers optimized for common beans (Phaseolus vulgaris L.) were tested (Table 2) to obtain molecular validation of the crossing method used regarding success in obtaining $F_{1}$ seeds (GAITÁN-SOLÍS et al., 2002). These primers were selected based on prior studies with lima beans in the BGP-UFPI (PENHA et al. 2017).

Table 2. List of primers developed for the species Phaseolus vulgaris L. used in distinguishing lima bean (Phaseolus lunatus L.) parents.

\begin{tabular}{|c|c|c|}
\hline Name & Sequence & Motif \\
\hline AG 1 & $\begin{array}{l}\text { F: CATGCAGAGGAAGCAGAGTG } \\
\text { R: GAGCGTCGTCGTTTCGAT }\end{array}$ & $(\mathrm{GA})_{8} \mathrm{GGTA}(\mathrm{GA})_{5} \mathrm{GGGGACG}(\mathrm{AG})_{4}$ \\
\hline BM 140 & $\begin{array}{l}\text { F: TGCACAACACACATTTAGTGAC } \\
\text { R: CCTACCAAGATTGATTTATGGG }\end{array}$ & $(\mathrm{GA})_{30}$ \\
\hline BM 141 & $\begin{array}{l}\text { F: TGAGGAGGAACAATGGTGGC } \\
\text { R: CTCACAAACCACAACGCACC }\end{array}$ & $(\mathrm{GA})_{29}$ \\
\hline BM 146 & $\begin{array}{l}\text { F: GAGATGAGTCCTTTCCCTACCC } \\
\text { R: TCGAGACACAATTTATGAAGGC }\end{array}$ & $(\mathrm{CTGTTG})_{4}(\mathrm{CTG})_{4}(\mathrm{TTG})_{3}(\mathrm{CTG})_{3}(\mathrm{CTG})_{4}$ \\
\hline BM 154 & $\begin{array}{c}\text { F: TCTTGCGACCGAGCTTCTCC } \\
\text { R: CTGAATCTGAGGAACGATGACCAG }\end{array}$ & $(\mathrm{CT})_{17}$ \\
\hline BM 156 & $\begin{array}{l}\text { F: CTTGTTCCACCTCCCATCATAGC } \\
\text { R: TGCTTGCATCTCAGCCAGAATC }\end{array}$ & $(\mathrm{CT})_{32}$ \\
\hline BM 160 & $\begin{array}{l}\text { F: CGTGCTTGGCGAATAGCTTTG } \\
\text { R: CGCGGTTCTGATCGTGACTTC }\end{array}$ & $(\mathrm{GA})_{15}(\mathrm{GAA})_{5}$ \\
\hline BM 211 & $\begin{array}{l}\text { F: ATACCCACATGCACAAGTTTGG } \\
\text { R: CCACCATGTGCTCATGAAGAT }\end{array}$ & $(\mathrm{CT})_{16}$ \\
\hline BM 212 & $\begin{array}{c}\text { F: AGGAAGGGATCCAAAGTCACTC } \\
\text { R:TGAACTTTCAGGTATTGATGAATGAAG }\end{array}$ & $(\mathrm{CA})_{13}$ \\
\hline GATS 91 & $\begin{array}{l}\text { F: GAGTGCGGAAGCGAGTAGAG } \\
\text { R: TCCGTGTTCCTCTGTCTGTG }\end{array}$ & $(\mathrm{GA})_{17}$ \\
\hline
\end{tabular}

Rev. Caatinga, Mossoró, v. 35, n. 1, p. 223 - 230, jan. - mar., 2022 
The primers were synthesized with an M13 tail of bacterial plasmid at the 5' end of the forward primer. The amplification reactions were performed with $10 \mathrm{ng}$ DNA, 1X PCR buffer, $2.0 \mathrm{mM} \mathrm{MgCl}$, $250 \mu \mathrm{g} / \mathrm{mL}$ BSA, $2.0 \mu \mathrm{M}$ dNTP, 1U Taq, $0.2 \mu \mathrm{M}$ direct primer, $0.4 \mu \mathrm{M}$ reverse primer, and $0.2 \mu \mathrm{M}$ M13-IrDye 700 or 800 , filling up with water to a final volume of $20 \mu \mathrm{L}$. Amplifications were made in a LifePro thermocycler (Bioer Technology Co. Ltd.) using initial denaturation at $94{ }^{\circ} \mathrm{C}$ for 2 minutes, followed by 45 amplification cycles at $94{ }^{\circ} \mathrm{C}$ for 30 seconds, $49{ }^{\circ} \mathrm{C}$ for 30 seconds, and $72{ }^{\circ} \mathrm{C}$ for 30 seconds, and final extension at $72{ }^{\circ} \mathrm{C}$ for 10 minutes. The amplification product was resolved on a 0.25 $\mathrm{mm}$ polyacrylamide gel $(6.5 \%)$, using an LI-COR 4300 DNA Analyzer (LI-COR Biosciences, USA). The alleles in each sample were identified using SAGA GT software (Li-Cor, Biosciences).

The LI-COR system used in genotyping detects DNA using infrared fluorescence. The chainterminated fragments were labelled with an infrared dye to be then separated according to size on an acrylamide gel. Raw image data comprised a series of bands displayed on a computer monitor to be then analyzed by the sequencer, using SAGA GT software.

The microsatellite markers were analyzed in terms of the presence or absence of informative bands for confirmation of cross-fertilization. Informative bands are alleles present in the male parent and absent in the female, whose presence in the supposed hybrid plant confirm cross-fertilization. Only bands with high clarity and reproducibility were considered informative bands (FALEIRO; PIRES; LOPES, 2003).

\section{RESULTS AND DISCUSSION}

The student's t-test proved the null hypothesis in which the mean number of buds opened in the morning is equal to those opened in the afternoon ( $\mathrm{p}$ value $>0.05)$ (Table 3). Therefore, artificial crossings in lima beans can be performed both in the morning and in the afternoon.

The number of lima bean flower buds opened at different periods shows that anthesis occurs throughout the morning and afternoon. Nevertheless, a larger number of flower buds open from 9:00 10:00 a.m. and from 4:00 to 5:00 p.m., with 33.33\% and $30 \%$ higher percentages, respectively (Table 3 ). Between 7:00 and 8:00 a.m., the first hours of the day, the presence of dew on the flowers makes it difficult to cross due to excess water on the stigma. For this reason, we started crossings at 8:00 a.m. In brief, flower morphology and opening time must be first understood to determine the proper time and temperature/ moisture conditions to perform crosses and obtain successful hybridizations (ANTUNES et al., 2010).

Table 3. Distribution of the number of flower buds of lima bean (Phaseolus lunatus L.) in anthesis in the morning and the afternoon and Student t-test.

\begin{tabular}{cccc}
\hline & \multicolumn{2}{l}{ Morning } \\
\hline Time (a.m.) & Absolute number & Relative number (\%) & Accumulated number \\
\hline 7:00 - 8:00 & 2 & 6.67 & 2 \\
$8: 00-9: 00$ & 7 & 23.33 & 9 \\
9:00 - 10:00 & 10 & 33.33 & 19 \\
10:00 - 1100 & 4 & 13.33 & 30 \\
11:00 - 12:00 & 7 & 23.33 & \\
\hline & & & Accumulated number \\
\hline Time (p.m.) & Absolute number & Relative number (\%) & 4 \\
\hline 1:00-2:00 & 4 & 13.33 & 16 \\
2:00-3:00 & 5 & 16.67 & 25 \\
3:00-4:00 & 7 & 23.33 & 30 \\
4:00-5:00 & 9 & 30.00 & \\
5:00-6:00 & 5 & 16.67 & \\
\hline p-value & 0.50 & & \\
t-critical & 1.89 & & \\
t-stat & 0.11 & & \\
\hline
\end{tabular}

Of the 241 crosses performed, the hybrid fruit formation rate was $5.8 \%$, and 42 seeds were obtained. The combination UFPI $666 \times$ UFPI 728 was not successful (Table 1). The method used allowed the formation of lima bean pods, although the rate of hybrid pod formation was low. This is 
fundamental for the breeding of the species $P$. lunatus L. since there is no other method described in the literature.

According to the literature consulted, low hybrid pod set rates are not a reason to reject a method. In a study carried out by Nunes et al. (2010) on cowpea artificial hybridization, of the 214 crosses performed, 19 pods were obtained, with a pod set rate of $8.87 \%$. Rêgo et al. (2006) evaluated four methods of crossing cowpea and obtained pod set rates from 2.9 to $44.9 \%$.

Pod set rates in crosses vary widely and depend on many factors. For a successful hybridization, crossing times, pollen viability, and pollination method must be previously evaluated (FREIRE FILHO et al. 2014). Grigolo and Fioreze (2018) reported that important aspects are a high specific combination between genotypes, associated with environmental conditions and handling techniques. To improve hybridization efficiency, Ribeiro and Storck (2003) suggested training operators and increasing the number of crossing operations are issues to be considered. Operator ability and climate conditions, among other factors, affect artificial pollination, with low temperatures and high relative humidity favoring pod set rates (RÊGO et al., 2006).

Pearson correlation coefficients showed that pod set percentages had a positive and significant correlation with minimum temperature $(0.75)$ and relative humidity $(0.77)$, but a negative and significant correlation with maximum temperature $(-0.82)$ (Table 4). Therefore, the smaller the temperature fluctuation and the higher the relative humidity, the higher the pod set rates. Such results indicate that to obtain greater success, lima bean crosses should be performed in a greenhouse, wherein these climatic elements can be controlled. Minimum and maximum temperatures inside the greenhouse were $22.9{ }^{\circ} \mathrm{C}$ and $34.1^{\circ} \mathrm{C}$, respectively, with an average relative humidity of $64 \%$.

Table 4. Pearson correlation coefficients among pod set $(\%)$, minimum temperature $\left({ }^{\circ} \mathrm{C}\right)$, maximum temperature $\left({ }^{\circ} \mathrm{C}\right)$, and relative humidity (\%).

\begin{tabular}{cccc}
\hline Variable & $\begin{array}{c}\text { Minimum temperature } \\
\left({ }^{\circ} \mathrm{C}\right)\end{array}$ & $\begin{array}{c}\text { Maximum temperature } \\
\left({ }^{\circ} \mathrm{C}\right)\end{array}$ & $\begin{array}{c}\text { Relative humidity } \\
(\%)\end{array}$ \\
\hline Pod set $(\%)$ & $0.75^{* *}$ & $-0.82^{* *}$ & $0.77^{*}$ \\
Minimum temperature $\left({ }^{\circ} \mathrm{C}\right)$ & & $-0.79^{* *}$ & $-0.84^{* *}$ \\
Maximum temperature $\left({ }^{\circ} \mathrm{C}\right)$ & & $0.88^{* *}$ \\
\hline
\end{tabular}

***: Significant at $1 \%$ and $5 \%$ probability by the $t$-test.

Freire Filho et al. (2014) evaluated studies of crossings in cowpea from 1982 to 2012 and concluded that temperature and relative humidity were the factors that most affected pod set rate in most of them. Similar results were obtained by Sousa et al. (2015), who described the ideal temperature and humidity for artificial crosses in lima beans to avoid heat stress and facilitate pollen grain release from anthers.

Floral bud size is one of the factors to consider for successful hybridizations. In the case of lima beans, it is one of the main hurdles in handling petals and tweezers and can reduce pod set rates. According to Frazão et al. (2010), the flower bud size of this species ranges from 5.30 to $6.00 \mathrm{~cm}$ on average.

The controlled crosses (UFPI $465 \times$ UFPI 728), (UFPI $628 \times$ UFPI 465), (UFPI $628 \times$ UFPI 666 ), and (UFPI $465 \times$ UFPI 628) were confirmed by obtaining F1 lima bean hybrids (Figure 1). Therefore, the proposed method was validated and parents had genetic complementarity. This result is important since there is still no methodology used in this crop. The combination UFPI $628 \times$ UFPI 666 stood out by exhibiting the highest pod set percentages (Table 4).

Of the microsatellite primers used and developed for the species Phaseolus vulgaris L., $40 \%$ of them (BM 211, BM 141, BM 154, and GAT 591) generated at least one informative band for confirmation of artificial cross-fertilization (Figure 2). Therefore, this marker was effective for confirming the occurrence or lack of crossfertilization in lima beans. Similar results were obtained by Morais et al. (2016), who applied 24 microsatellite markers to evaluate the effectiveness of controlled crosses and evaluate the genetic identity of seed samples of a common bean cultivar. 


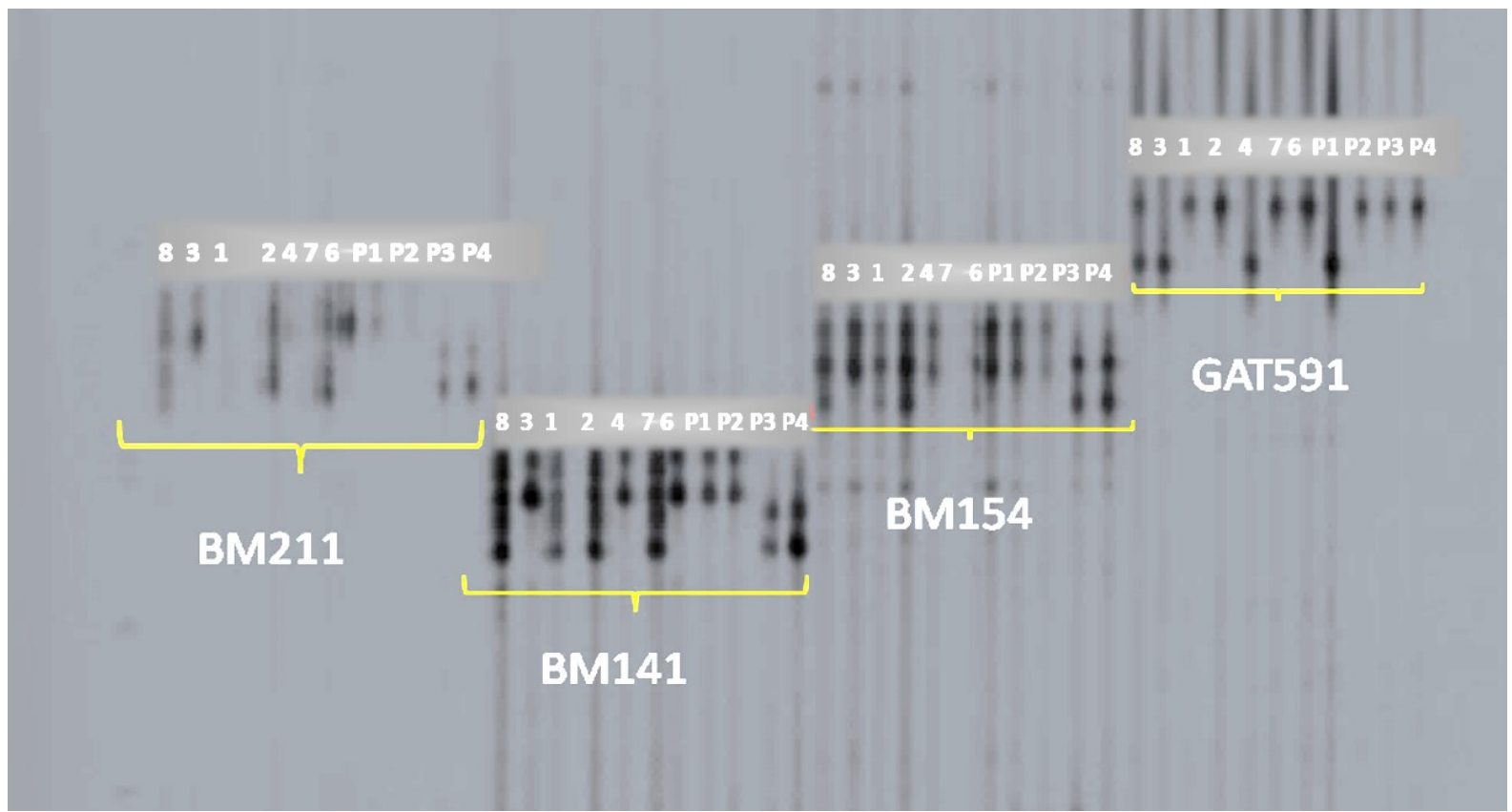

Figure 2. Highlighted profile of gels for the primers BM 211, BM 141, BM 154, and GAT 591 analyzed in lima bean (Phaseolus lunatus L.) plants in Teresina, PI, Brazil, 2016. The numbers 1, 2, 3, 4, 6, 7, and 8 correspond to the plants of the $\mathrm{F}_{1}$ generation of the combinations between the genotypes $\mathrm{P}_{1}$ (UFPI 465), $\mathrm{P}_{2}$ (UFPI 666), $\mathrm{P}_{3}$ (UFPI 628), and $\mathrm{P}_{4}$ (UFPI 728).

Other applications of microsatellites in lima bean plants were related to genetic diversity and identification of cross-fertilization rates (PENHA et al., 2017; OLIVEIRA-SILVA et al., 2017). In characterization studies on lima and other bean species of the genus Phaseolus by molecular markers, microsatellites have proven to be effective in tests for kinship determination (VIDAK et al., 2017; GIOIA et al., 2019). Therefore, the use of one or two microsatellite primers with at least one informative band is sufficient to confirm or deny cross-fertilization in lima beans.

Microsatellite markers were effective in confirming the paternity of interspecific $F_{1}$ hybrids between Vitis labruscana and Muscadinia rotundifolia obtained through artificial crosspollination and for determining the correct identity of the parents (SCHUCK et al., 2011).

\section{CONCLUSION}

Lima beans can be crossed artificially in the morning and afternoon. The crossing method without emasculation is efficient to obtain hybrids in lima beans. The genotypes UFPI 465, UFPI 728, UFPI 628, and UFPI 666 can be indicated as complementary parents for the breeding program of this species. The primers BM 211, BM 141, BM 154, and GAT 591 were efficient in differentiating accessions of lima beans from crossings.

\section{REFERENCES}

ANTUNES, I. F. et al. Melhoramento do feijão ao alcance de todos: I. cruzamentos. 2010. 1. ed. Pelotas, RS: Embrapa Clima TemperadoDocumentos, 2010. 38 p.

BLISS, F. A. Common bean. In: FEHR, W. R.; HADLEY, H. H. (Eds). Hybridization of crop plants. Madison, Wisconsin, USA: American Society of Agronomy, 1980. v. 1,cap. 17, p. 273-284.

CRUZ, C. D. GENES: software para análise de dados em estatística experimental e em genética quantitativa. Acta Scientiarum. Agronomy, 35: 271 $-276,2013$.

DOYLE J. J; DOYLE, J. L. Isolation of plant DNA from fresh tissue. Focus, 12: 13-15, 1990.

FALEIRO, F. G.; PIRES, J. L.; LOPES, U. V. Uso de marcadores moleculares RAPD e microssatélites visando a confirmação da fecundação cruzada entre Theobroma cacao e Theobroma grandiflorum. Agrotrópica, 15: 41-46, 2003.

FÉLIX, D. T.; COELLO-COELLO, J.; MARTÍNEZCASTILLO, J. Wild to crop introgression and genetic diversity in Lima bean (Phaseolus lunatus L.) in traditional Mayan milpas from Mexico. Conservation Genetics 15: 1315-1328, 2014. 
FRAZÃO, J. E. M. et al. Morfologia e fenologia de dez variedades de fava nas fases vegetativa e de inflorescência. Agropecuária Técnica, 31: 18-24, 2010.

FREIRE FILHO, F. R. et al. Cruzamentos de feijão -caupi [Vigna unguiculata (L) Walp.] realizados na Embrapa Meio-Norte, no período de 1982 a 2012. 1. ed. Teresina: Embrapa Meio-Norte, 2014. $120 \mathrm{p}$

GAITÁN-SOLÍS, E. et al. Microsatellite Repeats in Common Bean (Phaseolus vulgaris) Isolation, Characterization, and Cross $\square$ Species Amplification in Phaseolus ssp. Crop Science, 42: 2128-2136, 2002.

GIOIA, T. et al. Evolution of SSR diversity from wild types to US advanced cultivars in the Andean and Mesoamerican domestications of common bean (Phaseolus vulgaris). PLoS One, 14: e0211342, 2019.

GRANJA, M. B. et al. Variedades de feijão-fava submetidas à níveis de salinidade e adubação orgânica. Colloquium Agrariae, 15: 104-114, 2019.

GRIGOLO, S.; FIOREZE, A. C. D. C. L. Potencial de hibridação entre cultivares de feijão comum de diferentes grupos gênicos. Colloquium Agrariae, 14: 67-78, 2018.

IBGE - Instituto Brasileiro de Geografia e Estatística. Banco de dados agregados: pesquisa: produção agrícola. Piauí, 2018. Disponível em: https://cidades.ibge.gov.br/brasil/pesquisa/14/10278? ano=2018 Acesso em: 01 ago. 2020.

MARTÍNEZ-CASTILLO, J. et al. Genetic structure within the Mesoamerican gene pool of wild Phaseolus lunatus (Fabaceae) from Mexico as revealed by microsatellite markers: implications for conservation and the domestication of the species. American Journal of Botany, 101: 851-864, 2014.

MORAIS, S. R. P. et al. Application of microsatellite markers to confirm controlled crosses and assess genetic identity in common bean. Crop Breeding and Applied Biotechnology, 16: 234-239, 2016.

NUNES E. D.et al. Hibridação artificial em feijãocaupi (Vigna unguiculata W.) em diferentes cultivares. In: ENCONTRO DE GENÉTICA DO NORDESTE - GENÉTICA, BIODIVERSIDADE E CONSERVAÇÃO, 2010, Jequié. Anais ... Jequié: UESB, 2010. p. 6.

OLIVEIRA-SILVA, R. N. et al. Diversidade fenotípica em cultivares de feijão-de-lima cultivadas no Brasil, utilizando a estratégia Ward-MLM. Revista Chilena de Pesquisa Agrícola, 77: 35-40, 2017.

ORMENO-ORRILLO, E. et al. Taxonomy of rhizobia and agrobacteria from the Rhizobiaceae family in light of genomics. Systematic and Applied Microbiology, 38: 287-291, 2015.

PENHA, J. S. et al. Estimation of natural outcrossing rate and genetic diversity in Lima bean (Phaseolus lunatus L. var. lunatus) from Brazil using SSR markers: implications for conservation and breeding. Genetic Resources and Crop Evolution, 64: 1-10, 2017.

RANGEL JÚNIOR, I. M. et al. Floral biology and physicochemical characterization of wild passion fruit Passiflora setacea BRS Pérola do Cerrado cultivated in the state of Rio de Janeiro. Revista Brasileira de Fruticultura, 40: 1-9, 2018.

RÊGO, M. et al. Avaliação de métodos de cruzamentos artificiais em feijão-caupi [Vigna unguiculata (L.) WALP]. In: CONGRESSO NACIONAL DE FEIJÃO-CAUPI, 6., 2006, Teresina. Anais... Teresina: Embrapa Meio-Norte, 2006. p. 1-4.

RIBEIRO, N. D.; STORCK, R. Genitores potenciais para hibridações identificados por divergência genética em feijão carioca. Ciência Rural, 33: 413421,2003

RUIZ-GIL, P. J. et al. Differentiation and genetic diversity of Phaseolus lunatus wild populations from Chiapas, México, and their genetic relationships with MI and MII groups. Botanical Sciences, 94: 701712,2016

SCHUCK, M. R. et al. Obtaining interspecific hybrids, and molecular analysis by microsatellite markers in grapevine. Pesquisa Agropecuária Brasileira, 46: 1480-1488, 2011.

SOUSA, A. M. C. B. et al. Determination of ideal conditions to do artificial crosses in Phaseolus lunatus L. Annual Report of the Bean Improvement Cooperative, 58: 95-96, 2015.

SILVA, M. V. S. et al. Caracterização morfoagronômica de fava (Phaseolus lunatus L.). Cadernos de Agroecologia, 10: 1-5, 2016.

VIDAK, M. et al. Microsatellite markers in common bean (Phaseolus vulgaris L.). Journal of Central European Agriculture, 18: 902-917, 2017.

This work is licensed under a Creative Commons Attribution-CC-BY https://creativecommons.org/licenses/by/4. 